\title{
Current state of Cenopopulations Iris Magnifica Vved and Tulipa Fosteriana W.Irving in Uzbekistan
}

\author{
Uktam Khujanazarov $^{1}$, Habibullo Shomurodov $^{2}$, Parida Mirkhamidova ${ }^{1, *}$, and Rano \\ Alimova $^{3}$ \\ ${ }^{1}$ Tashkent State Pedagogical University, Bunyodkor Road, 27, Tashkent, Uzbekistan, 100183 \\ ${ }^{2}$ Institute of Botany, Durmon Yuli str., 32, Tashkent, Uzbekistan, 100125 \\ ${ }^{3}$ Tashkent State Agrarian University, University str., 2, Tashkent province, Uzbekistan, 100140
}

\begin{abstract}
The current state of cenotic populations of 2 plant species listed in the Red Book of the Republic of Uzbekistan from the territories of Kashkadarya province was assessed, such as: Iris magnifica Vved. and Tulipa fosteriana $W$. Irving. The presence or absence of certain ontogenetic groups in coenopopulation is associated with the ecological-phytocenotic growth condition and the degree of cattle grazing. The aim of the research was to describe the coenopopulation of Iris magnifica Vved. and Tulipa fosteriana W. Irving. The scientific justification of the ways of ecological improvement of coenopopulation. In the implementation of scientific work, the methods of traditional geobotanical and cartographic remote study of plant formations were applied. The factors that influence the vegetative processes of plant formations were identified in this study so that the ontogenetic structure of coenopopulation of Iris magnifica Vved. and Tulipa fosteriana W. Irving. were developed.
\end{abstract}

\section{Introduction}

One of the leading branches of agriculture is animal husbandry, and it is important to conduct a scientific, practical study, assessment of the material source of its development natural food (source of hay) - pasture types [1, 2, 10-12]. The types of pastures - natural territorial complexes with similar climate, soil, productivity (fertility), the time of year, when cattle are grazed and types are determined by the edificatory types of plant families $[3,9]$. There is a need to determine their ecological status: structure, composition, productivity (fertility), and degree of damage (degradation, transformation), types of damage factors (damage), and other quantitative and qualitative indicators $[4,5]$. The foothill pastures of the Kashkadarya Basin are one of the main bases for the development of animal husbandry, in recent years the productivity (fertility) of which is reduced under the influence of metrological factors.

Kashkadarya province includes the Karshi depression in southern Uzbekistan, bordered in the north by the mountains of Koratepa, Zarafshan ranges, Zirabulok, and Ziyevuddin; in

${ }^{*}$ Corresponding author: parida.mirkhamidova@mail.ru 
the east - by the foothills of the southwestern part of the Gisar ridge [6]. As a result of the study, we analyzed the plant species of mountain pastures and determined the current state of pastures in the Kashkadarya Basin.

\section{Materials and methods}

Field research was performed during June 2018 by traditional phytosociological methods with description of plant associations, collection of herbarium specimens and photographing of surveyed plots. Demographic structure of plant populations and the age indexes was studied. The ontogenetic structure of coenopopulations in the different ecological and phytocenotical conditions was determined by the transect method $[7,8]$.

During field research, we studied two cenotic populations of Iris magnifica VVed (Figure 1). The first cenopopulation grows in the Zeravshan ridge. It is registered as a part of a herb-kavrak-pink community on the southeastern slope of the Zeravshan Range (Takhta-Karacha Pass). The soil of the described area is typical sierozem, large-stony.

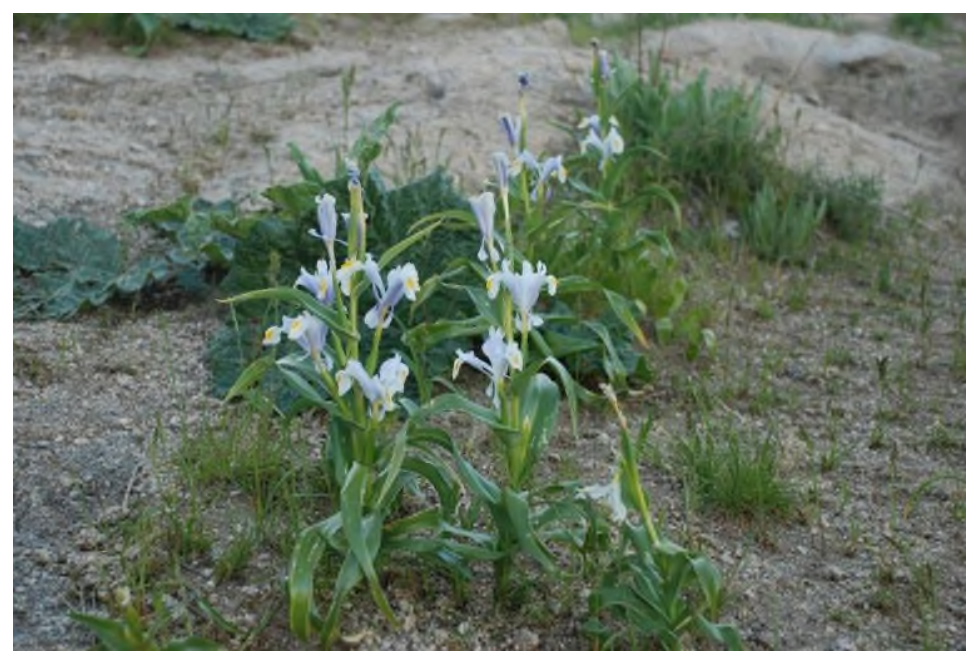

Fig. 1. Iris magnifica

The total projective grass cover is $75 \%$. The high density of herbage is associated with the absence of anthropogenic impact (the described site is located in a fenced area). At the same time, the share of the studied species does not exceed $4 \%$. The floristic composition of the community is quite rich and consists of 28 species of vascular plants (Table 1). 
Table 1. Species composition of the herb-kavrak-pink community

\begin{tabular}{|c|c|c|c|}
\hline$\#$ & Name of plants & Life form & Projective cover, \% \\
\hline 1 & Rosa maracandica & Bush & 10 \\
\hline 2 & Amygdalus spinosissima & Bush & 20 \\
\hline 3 & Ferula kuhistanica & Many & 4 \\
\hline 4 & Iris magnifica & Many & 2 \\
\hline 5 & Eremurus hissaricus & Many & + \\
\hline 6 & Tulipa fosteriana & Many & 4 \\
\hline 7 & Elytrigia trichophora & Many & 14 \\
\hline 8 & Carex pachystylis & Many & 4 \\
\hline 9 & Hypericum perforatum & Many & 8 \\
\hline 10 & Poa bulbosa & Many & 2 \\
\hline 11 & Centaurea squarrosa & Many & + \\
\hline 12 & Gentiana olivieri & Many & 2 \\
\hline 13 & Poa pratensis & Many & + \\
\hline 14 & Allium pratense & Many & + \\
\hline 15 & Ixiolirion tataricum & Many & + \\
\hline 16 & Cousinia radians & Many & + \\
\hline 17 & Veronica stylophora & Single & + \\
\hline 18 & Geranium pusillum & Single & + \\
\hline 19 & Parentucellia flaviflora & Single & + \\
\hline 20 & Gallium sp. & Single & + \\
\hline 21 & Cerastium glomeratum & Single & 3 \\
\hline 22 & Bromus tectorum & Single & + \\
\hline 23 & Ranunculus olgae & Single & + \\
\hline 24 & R. sewerzowii & Single & + \\
\hline 25 & Turgenia latifolia & Single & + \\
\hline 26 & Thlaspi perpholiatum & Single & + \\
\hline 27 & Myosotis refracta & Single & \\
\hline & & & + \\
\hline
\end{tabular}

The second cenopopulation was studied on the northern slope of the ridge (also in the Takhta-Karacha region) along a dirt road. The plant community is dominated by Ferula kuhistanica, Centaurea squarrosa, and Elytrigia trichophora. The soil is large-stony. The total projective cover of the grass stand does not exceed $44 \%$, and the projective cover of the studied species in this community reaches $8-10 \%$ (Figure 2).

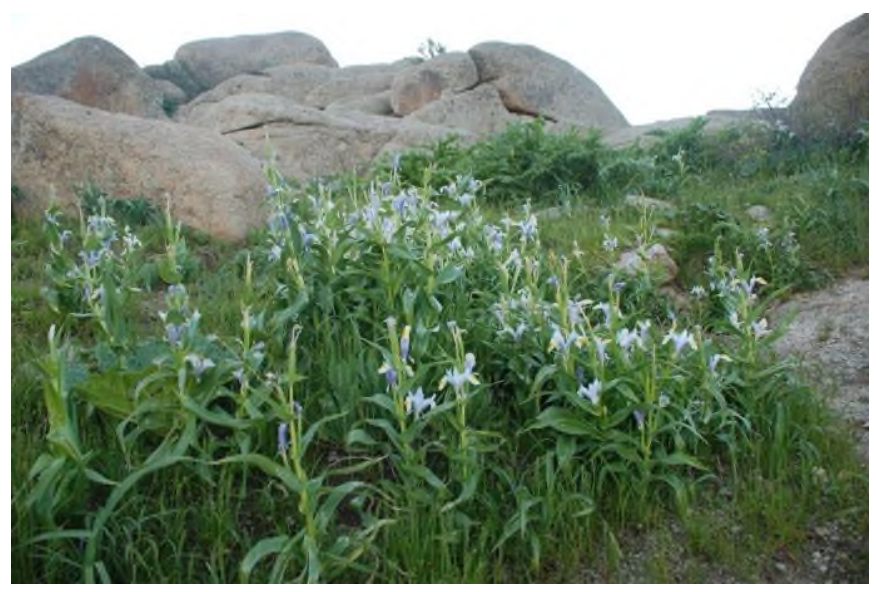

Fig. 2. Iris-kavrak community on the Zeravshan ridge 
The floristic composition of the community consists of 19 species of vascular plants, the vast majority of which are perennials (47\%). The share of shrub species is small (one type of shrub and one half-shrub) (Table 2).

Table 2. Species composition of the herb-kavrak community

\begin{tabular}{|c|c|c|c|}
\hline$\#$ & Name of plants & Life form & Projective cover, \% \\
\hline 1 & Cerasus erythrocarpa & Bush & 3 \\
\hline 2 & Ferula kuhistanica & Many & 8 \\
\hline 3 & Elytrigia trichophora & Many & 6 \\
\hline 4 & Helichrysum mussae & Many & + \\
\hline 5 & Astragalus $s p$ & Many & 8 \\
\hline 6 & Iris magnifica & Many & 3 \\
\hline 7 & Centaurea squarrosa & Many & + \\
\hline 8 & Onosma maracandicum & Many & + \\
\hline 9 & Dianthus uzbekistanicus & Many & 2 \\
\hline 10 & Poa pratensis & Many & + \\
\hline 11 & Poa bulbosa & Many & 4 \\
\hline 12 & Verbascum songaricum & Twin & 3 \\
\hline 13 & Diarthron vesiculosum & Single & + \\
\hline 14 & Bromus tectorum & Single & + \\
\hline 15 & Veronica stylophora & Single & + \\
\hline 16 & Thlaspi perpholiatum & Single & + \\
\hline 17 & Koelpinia linearis & Single & Single \\
\hline 18 & Ceratocephala testiculata & \multicolumn{3}{|c|}{} \\
\hline
\end{tabular}

The ontogenetic structure of Iris magnifica cenopopulations has not been studied previously. We have studied the ontogenetic structure of two CPs (Cenopopulation) Iris magnifica growing on the Zeravshan Range.

\section{Results and discussion}

The ontogenetic structure of the studied CP has two types of spectrum: left-sided (CP1) and centered ( $\mathrm{CP} 2)$. In the first cenopopulation, young plant fractions predominate, and the absolute maximum falls on juvenile individuals. Their percentage in the coenopopulation is $29.5 \%$. The distribution of individuals of other ontogenetic groups in the left sati of the spectrum has the following patterns: immature $-10.0 \%$, virginal $-10.5 \%$, young generative individuals $-24.5 \%$. The share of mature generative individuals in the cenopopulation is $21.0 \%$. Individuals of the old generative state do not exceed $5 \%$. At the time of the study, no senile plants were found (Figure 3). 


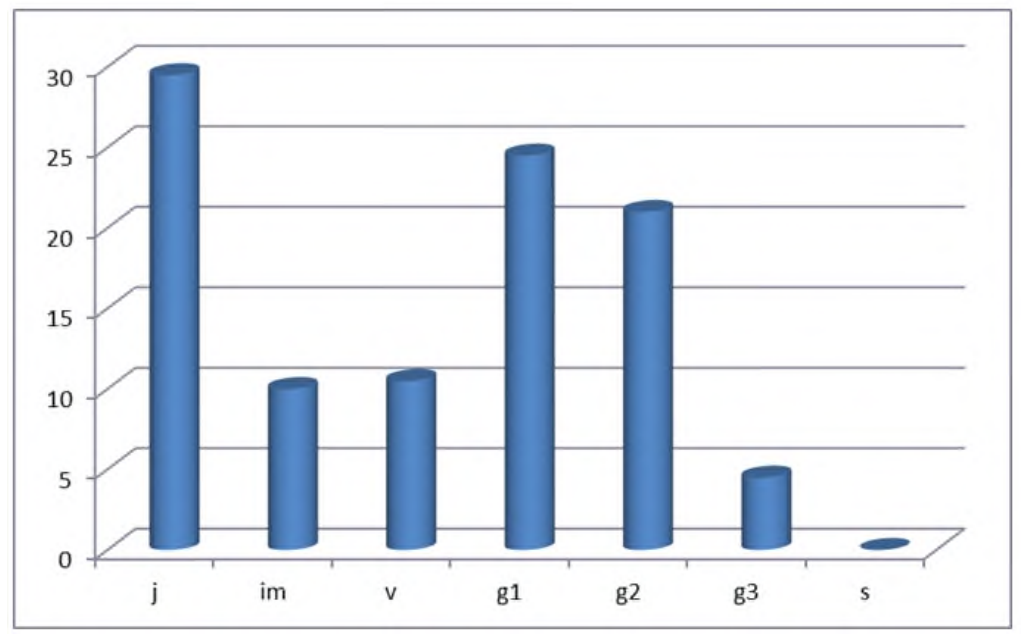

Fig. 3. Ontogenetic structure of Iris magnifica cenopopulations (CP1)

The predominance of juvenile individuals in the cenopopulation is associated with a favorable growth condition. The cenopopulation grows on the eastern slope of the ridge along temporary streams and is protected from wind erosion. In addition, this section of the ridge is fenced off by the local population for making hay, and thus, it is protected from intensive grazing. Adequate moisture and lighting contribute to the successful seed regrowth of the cenopopulation. A decrease in the proportion of individuals in immature and virginal states is the result of the lunge of most young (juvenile) individuals due to the wide distribution of tall perennials and shrubs here.

In the second cenopopulation, the peak was noted in mature generative plants $(24.0 \%)$. The number of individuals on the left side of the spectrum is much greater than on the right. This is typical for the vast majority of tuberous plants in the region. In the left part of the spectrum, juvenile and young generative individuals prevail; their percentage in the cenopopulation is slightly higher than $14 \%$. The reasons for the high proportion of juvenile individuals in comparison with immature and virginal individuals are given above (see $\mathrm{CP} 1$ ), the predominance of young generative individuals is associated with the rapid pace of development of immature and virginal individuals (Figure 4).

The dominance of middle-aged generative individuals in the second cenopopulation, on the one hand, is associated with the elimination of young individuals due to the weather conditions of the year (spring frosts, mudflows), intensive grazing (the second CP grows outside the enclosed territory), and, on the other hand, the duration of the continuation of life in this age condition. The ontogenetic spectrum of this cenopopulation coincides with the characteristic one. 


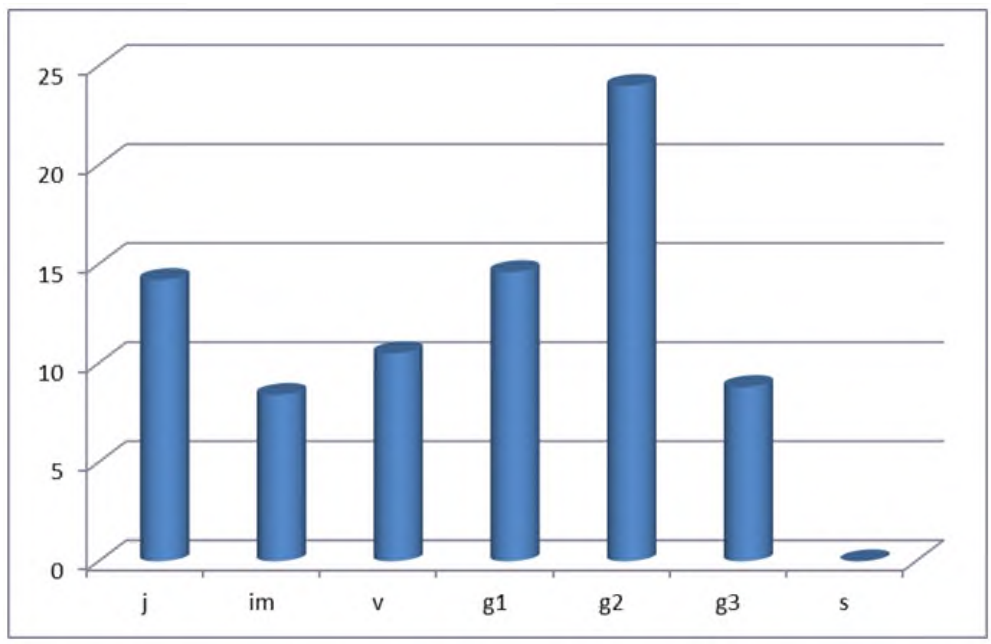

Fig. 4. Ontogenetic structure of Iris magnifica cenopopulations (CP2)

Two coenotic populations of $T$. fosteriana were studied in different ecologicalphytocenotic conditions of the Zeravshan Range (Figure 5).

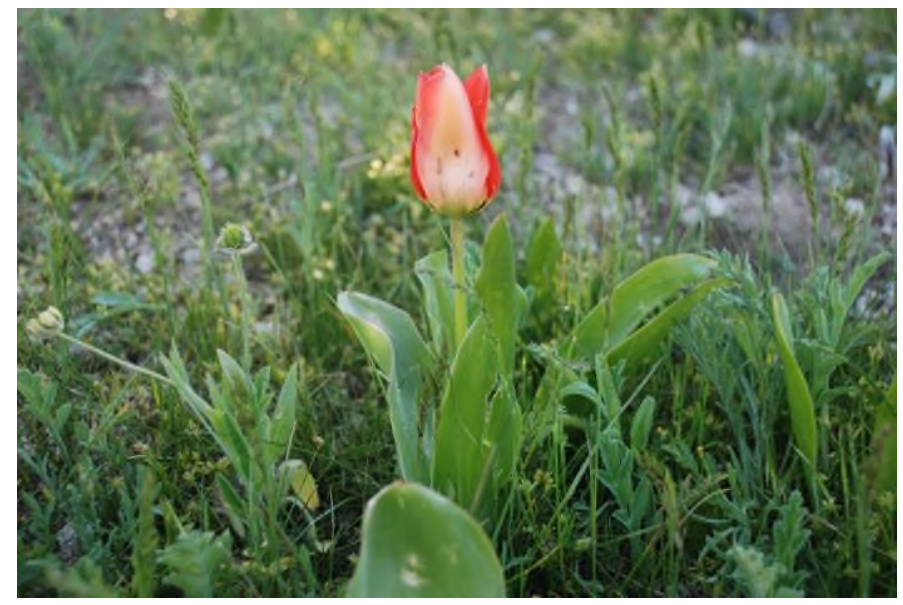

Fig. 5. General view of Tulipa fosteriana

Both cenopopulations of the species were studied in the Zeravshan ridge in the area of the Takhta-Karacha pass. The first cenopopulation grows in the composition of the herbkavrak-pink community on the southeastern slope of the Zarafshan Range, together with the Iris magnifica cenopopulations. As noted above, the soil of the described site is typical sierozem, large-stony. The total projective grass cover is $75 \%$. The high density of herbage is associated with the absence of anthropogenic impact (the described site is located in a fenced-in area). At the same time, the share of the investigated species does not exceed $1 \%$. The floristic composition of the community consists of 27 species of vascular plants (Table 3).

The second coenopopulation of Tulipa fosteriana grows on the eastern exposure of the drive of the separate part of the Zeravshan Ridge as part of the Kavrakov-Badamchay community. The soil of the described area is fine earth, in places stony. The total projective 


\section{EMMFT-2020}

cover of the herbage reaches $51 \%$. The vegetation cover is dominated by Ferula kuhistanica and Amygdalus spinosissima. The floristic composition of the community consists of 24 species of vascular plants (Table 3).

Table 3. Species composition of the Kavrak-Badamchay community

\begin{tabular}{|c|c|c|c|}
\hline$\#$ & Name of plants & Life form & Projective cover, $\%$ \\
\hline 1 & Amygdalus spinosissima & Bush & 5 \\
\hline 2 & Amygdalus bucharica & Bush & 2 \\
\hline 3 & Cerasus erythrocarpa & Bush & 1 \\
\hline 4 & Acanthophyllum serawschanicum & Bush & 20 \\
\hline 5 & Ferula kuhistanica & Many & 2 \\
\hline 6 & Ferula diversivittata & Many & + \\
\hline 7 & Gagea capusii & Many & + \\
\hline 8 & Gagea gageoides & Many & + \\
\hline 9 & Tulipa fosteriana & Many & + \\
\hline 10 & Tulipa turkestanica & Many & + \\
\hline 11 & Astragalus sp. & Many & + \\
\hline 12 & Scarioila orientalis & Many & + \\
\hline 13 & Carydalis lededbouriana & Many & + \\
\hline 14 & Iris stolonifera & Many & 2 \\
\hline 15 & Allium pratense & Many & 5 \\
\hline 16 & Hypericum perforatum & Many & 4 \\
\hline 17 & Thymus seravschanicus & Many & 1 \\
\hline 18 & Poa bulbosa & Many & + \\
\hline 19 & Poa pratensis & Many & + \\
\hline 20 & Centaurea squarrosa & Many & + \\
\hline 21 & Cousinia radians & Many & + \\
\hline 22 & Geranium pusillum & Single & Single \\
\hline 23 & Ranunculus paucidentatus & Single & \\
\hline 24 & Turgenia latifolia & & + \\
\hline
\end{tabular}

The ontogenetic structure of Tulipa fosteriana has not been previously studied by anyone. To assess the state of cenopopulations on the basis of demographic indicators of cenopopulations, data collected in the current year during field studies were used (Figure 6). Senile individuals are absent in both cenopopulations. The absence of senile plants in bulbous cenopopulations is associated with the death of most individuals in generative ontogenetic states.

Based on the peculiarities of the species biology (high seed productivity, the presence of vegetative reproduction due to stolons, the slowest rate of development of individuals in the virginal state), the characteristic spectrum of cenopopulations of this species will be the left-sided type with a peak in juvenile individuals. At the time of research, the ontogenetic spectrum of both the first and cenopopulations as a whole coincides with the characteristic (only the peak falls on immature individuals).

In the first cenopopulation age groups are distributed as follows: juvenile $-29.3 \%$, immature $-57.2 \%$, virginal -9.3 and generative only $4.1 \%$ (senile are absent), and in the second $31.0 \% ; 23.3 \% ; 41.2 \% ; 4.4 \%$ and $0.0 \%$, respectively. 


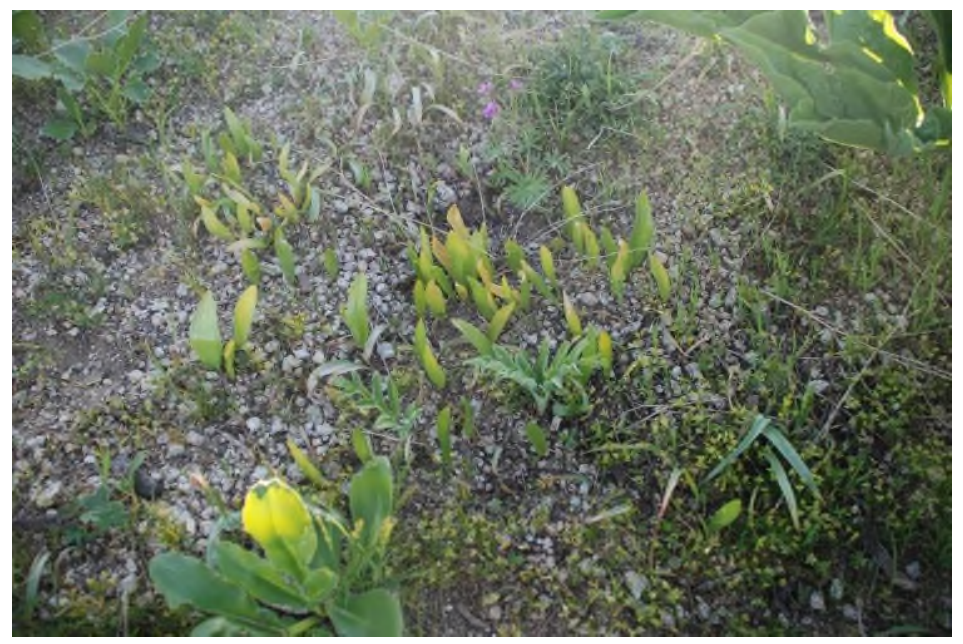

Fig. 6. Virginal specimens

The high value of juveniles in the first cenopopulation is associated with high seed productivity of generative individuals and high seed germination. The predominance of immature individuals in the first cenopopulation is a result of the high survival rate of young individuals (juveniles) and the presence of vegetative reproduction due to stolons in an immature age state. But, due to the high pressure of competitive species, not all immature individuals pass to the virginal age state (Figure 7).

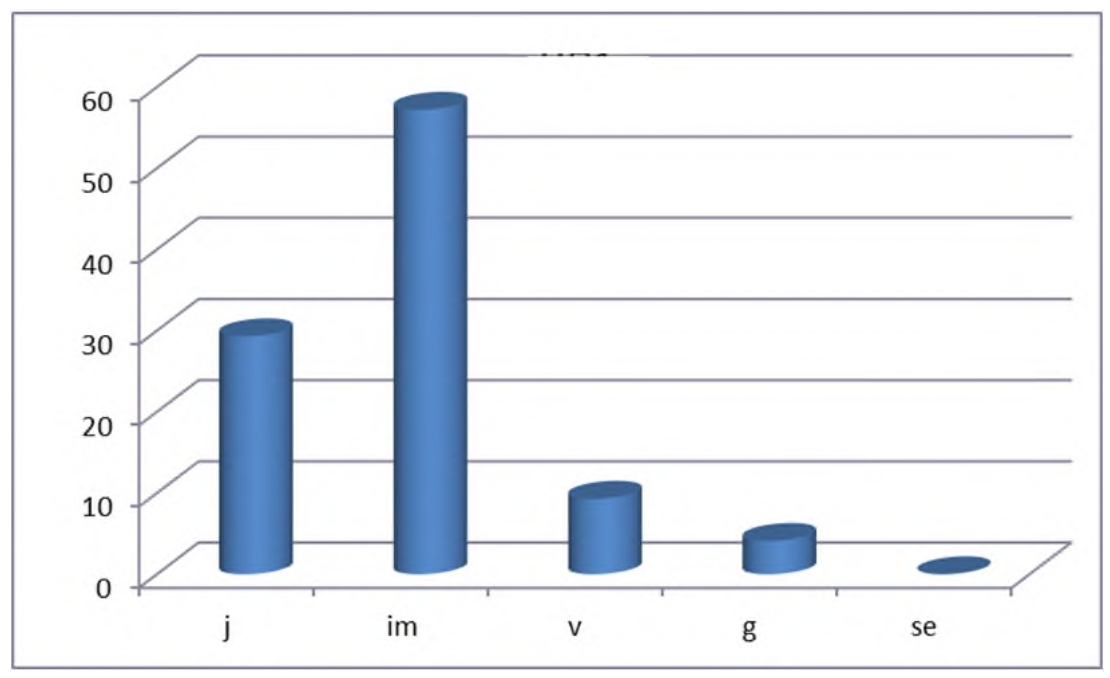

Fig. 7. Ontogenetic structures of $T$. fosteriana cenopopulations (CP1)

A negligible percentage of generative individuals at the time of the study is certainly associated with the collection of flowering plants in bouquets. Let us recall that both cenopopulations grow in the area of the Takhta-Karachi pass, where dozens of young people, during the tulip blooming period, are engaged in the sale of tulip bouquets.

The ontogenetic spectrum of the second cenopopulation is also left-sided. The peak in the spectrum falls on virginal plants (Figure 8). 


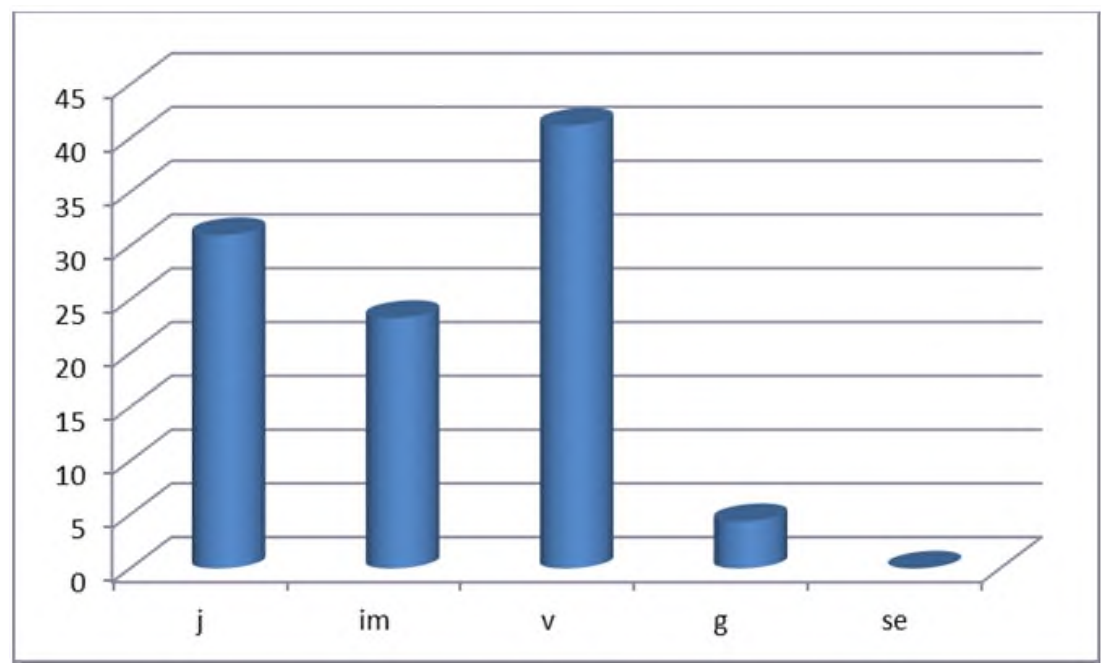

Fig. 8. Ontogenetic structures of $T$. fosteriana cenopopulations (CP2)

This variant of the spectrum is formed with abundant fruiting and the longest life span of individuals in a given age state.

In this cenopopulation, as in the previous one, the proportion of generative individuals is low. It does not exceed $4.4 \%$. The low value of the proportion of generative individuals in the cenopopulation is associated with the recreational process.

\section{Conclusion}

Thus, the studied cenopopulations of Iris magnifica in different ecological-phytocenotic conditions are satisfactory. Individuals go through all stages of ontogenesis. Ontogenetic spectra differ due to ecological-phytocenotic growing conditions and different degrees of anthropogenic load.

The studied coenopopulations of T. fosteriana are normal, incomplete. The absence of senile individuals in the surveyed cenopopulations is associated with the biological peculiarity of the species. In tulips, like many geophytes, most individuals end their long life cycles in a generative state. The ontogenetic spectra of the studied cenopopulations coincide with the characteristic one, and thus reflect the biological characteristics of the species.

\section{References}

1. K. B. Dias, R. M. Barrerios, Periodico Tche Quimica 15(30), 241-251 (2018)

2. A. Galnaityte, I. Krisciukaitiene, Public Policy and Administration 16(2), 264-278 (2017)

3. N. B. Glotov, Plant life in heterogenic environment 1, 146-149 (1998)

4. U. Khuzhanazarov, Bulleting of Agrarian Sciences 1-2(47-48), 111-114 (2012)

5. U. Khujanazarov, H. Shomurodov, E. Afonina, The Asian International Journal of Life Sciences 21(1), 1-11 (2019)

6. A. Jumanov, S. Khasanov, A. Tabayev, G. Goziev, U. Uzbekov, E. Malikov, IOP Publishing 614(1), 012150 (2020) 
7. V. Lebedev, N. Subbotina, V. Kirkach, E. Vidjagina, I. Pozdnyakov, K. Shestibratov, Periodico Tche Quimica 15(1), 120-125 (2018)

8. B. Mirkin, L. Naumova, A. Solomeshch, The Modern Science of Vegetation, 264 (Logos Press, Moscow, 2000)

9. M. S. Poškus, R. P. Valickienè, A. Kuzinas, Public Policy and Administration 17(4), 619-633 (2018)

10. A. Schwendemann, Zeitschrift fur Gefassmedizin 14(1), 17-18 (2017)

11. G. Silbernagel, Zeitschrift fur Gefassmedizin 15(2), 12-13 (2018)

12. M. Sukhova, O. Zhuravleva, Y. Vinokurov, E. Chernova, M. Kaizer, Periodico Tche Quimica 15(1), 537-547 (2018) 